\title{
THE NEED FOR AN ADDITIONAL NOTICE AND COMMENT PERIOD WHEN FINAL RULES DIFFER SUBSTANTIALLY FROM INTERIM RULES
}

Through the promulgation of rules and regulations that carry the force of law, federal administrative agencies have a considerable impact on the personal and proprietary interests of American citizens. ${ }^{1}$ In order "to afford parties affected by administrative [rulemaking] a means of knowing what their rights are and how they may be protected,"2 agencies are required to follow the rulemaking procedures enacted by Congress in the Administrative Procedure Act (APA). ${ }^{3}$ Compliance with these procedural requirements is designed to ensure informed and rational agency rulemaking; courts therefore rely on strict review of an agency's rulemaking procedures to achieve substantively sound administrative law. ${ }^{4}$

1. The pervasive impact of the administrative process is reflected by the number of subjects it covers, including air and water pollution; prices of electricity, gas, telephone, and other utility services; rates, schedules, and services of airlines, street cars, and buses; wholesoneness of meat aud poultry; fraud or inadequate disclosure in the sale of securities; conditions in loconotives, ships, airplanes, bridges, and elevators; unfair labor practices; false advertising; the adequacy of safety appliances; unemployment coinpensation; bank deposits and credits; and wages. K. DAvis, ADMINISTRATIVE LAW TEXT 3 (3d ed. 1972).

2. S. Rep. No. 752, 79th Cong., Ist Sess. 7 (1945) [hereinafter cited as Senate RePorT], reprinted in Legislative History of the Administrative Procedure Act, S. Doc. No. 248, 79th Cong., 2d Sess. 193 (1946) [hereinafter cited as APA LegisLAtive HistoRY].

3. Ch. 324, $\S \S 1-12,60$ Stat. 237 (1946) (current version codified in scattered sections of 5 U.S.C.). See text accompanying notes $9-17$ infra.

4. See Weyerhaeuser Co. v. Costle, 590 F.2d 1011, 1028-31 \& n.15 (D.C. Cir. 1978); International Harvester Co. v. Ruckelshaus, 478 F.2d 615, 651 (D.C. Cir. 1973) (Bazelon, C.J., concurring). In Weyerhaeuser the court stated its willingness "to entrust the Agency with wide-ranging regulatory discretion... so long as we are assured that its promulgation process as a whole and in each of its major aspects provides a degree of public awareness, imderstanding, and participation commensurate with the complexity and intrusiveness of the resulting regulations." $590 \mathrm{~F} .2 \mathrm{~d}$ at 1028. See also McGowan, Reflections on Rulemaking Review, 53 TUL. L. Rev. 681, 690-96 (1979).

Judicial review of agency rulemaking is not restricted solely to the agency's promulgation procedures but also extends to the substantive aspects of the rule or regulation. Although the courts are permitted to conduct a "searching and careful" inquiry into the facts supporting the rule, "the ultimate [substantive] standard of review is a narrow one." Citizens to Preserve Overton Park, Inc. v. Volpe, 401 U.S. 402, 416 (1971). The APA empowers courts to set aside only inforinal agency action that is "arbitrary, capricious, an abnse of discretion, or otherwise not in accordance with law." 5 U.S.C. § 706(2)(A) (1976). Strict and careful review of an agency's rulemaking procedures, therefore, renains the primary safeguard against arbitrary agency action. For suminaries of the divergent judicial positions concerning the scope and standard of review of informal 
Serious questions about the adequacy of agency rulemaking procedures arise when an agency publishes a final rule that differs substantially from its earher proposed or interim rule. The primary concern in such situations is that the proposed or interim rule may fail to give interested parties adequate notice of the scope and substance of the final rule..$^{5}$ The provision of adequate notice is particularly important with respect to rules that undergo substantial revision because it ensures that interested parties are given a meaningful opportunity to participate in the rulemaking process and are not completely unprepared for the significant changes embodied in the agency's final rule.

Both Congress and the courts have considered the problem of substantial cliange between an agency's proposed and final rules; they have failed, however, to consider separately substantial change between an agency's interim and final rules. ${ }^{6}$ This failure must be remedied; the impact of substantial changes on parties subject to the agency's rule increases significantly when that change occurs between a rule's interiun and final stages. ${ }^{7}$

This comment examines the problem of substantially revised rules in light of the purposes behind the APA's notice and comment provisions. ${ }^{8}$ It first traces the developinent of stricter rulemaking notice requirements and explains why these developments have raised questions about the sufficiency of notice provided by proposed and interim rules that differ significantly from their final form. Second, it outlines the factors courts have apphed when reviewing final rules that differ from their proposed form and discusses why these factors must be strictly applied. Finally, it exammes the distinctive characteristics of interim rules and argues that these characteristics coinpel a nore frequent imposition of an additional notice and comment period when an agency makes substantial changes in a rule between its interim and final stages.

\section{The Administrative Procedure Act's Rulemaking Provisions}

The APA's informal" or "notice and cominent" provisions ${ }^{10}$ pre-

agency rulemaking, see K. Davis, Administrative LAw of the SeVEnties $\$ \S 29.01-1, .01-8$, at 654-83 (1976); Note, Judicial Review of Agency Rule Making, 14 GA. L. Rev. 300 (1980).

5. The APA's notice requirements are set forth in 5 U.S.C. § 553(b) (1976). See text accompanying notes 26-33 infra.

6. See note 94 infra and text accompanying notes 93-94 infra.

7. See notes 146-50 infra and accompanyimg text.

8. See text accompanying notes 31-32 infra.

9. The term "informal" describes rulemaking that is not subject to the requirement of a formal hearing. See 5 U.S.C. \& 553(b) (1976). The procedural requirements for formal, on-therecord rulemaking are contamed in id. $\$ \S 556,557$. The formal rulemaking procedure requires "trial type" hearings, mcluding the right to submit evidence and to cross-examme. See id.; B. SCHWARTZ, ADMINISTRATIVE LAW 172-73 (1976).

10. 5 U.S.C. $\$ 553$ (b)-(c) (1976). These sections provide in part: 
scribe the minimum procedural requirements ${ }^{11}$ that agencies must follow when promulgating substantive ${ }^{12}$ rules or regulations. These minimum requirements imvolve a four-step process of administrative rulemaking. First, to initiate this process, an agency must publish a notice of proposed rulemaking in the Federal Register. ${ }^{13}$ This notice must state the tinie, place, and nature of the rulemaking proceedings; it must refer to the legal authority for the rule and state "either the terms or substance of the proposed rule or a description of the subjects and issues involved."14 Second, after the required notice is published, the agency must "give interested persons an opportunity to participate in the rule making througl submission of written data, views or arguments with or without the opportunity for oral presentation."15 These two steps constitute the notice and comment period. Third, after considering the information submitted during the notice and comment period, the agency must "mcorporate in the rules adopted a concise

(b) General notice of proposed rule making shall be published in the Federal Register.... The notice shall includeings;

(1) a statement of the time, place, and nature of public rule making proceed-

(2) reference to the legal authority under which the rule is proposed; and

(3) either the terms or substance of the proposed rule or a description of the subjects and issues involved. ...

(c) After notice required by this section, the agency shall give interested persons an opportunity to participate in the rule making through subınission of written data, views, or arguments with or without opportunity for oral presentation. After consideration of the relevant matter presented, the agency shall incorporate in the rules adopted a concise general statement of their basis and purpose.

11. H.R. REP. No. 1980, 79th Cong., 2d Sess. 25 (1946) [hereinafter cited as House REPORT], reprinted in APA LEGISLATIVE HISTORY, supra note 2, at 259; SENATE REPORT, supra note 2, at 14, reprinted in APA LEgislative History, supra note 2, at 200. See also Vermont Yankee Nuclear Power Corp. v. Natural Resources Defense Council, Inc., 435 U.S. 519, 524 (1978) (generally speaking, section 553 "established the maximum procedural requirements that Congress was willing to have the courts inpose upon agencies in conducting rulemaking procedures"); A.O. Smith Corp. v. FTC, 396 F. Supp. 1125, 1133 (D. Del. 1975), aff'd in part, vacated in part on other grounds, 530 F.2d 515 (3d Cir. 1976); 1 K. Davis, ADMINISTRATIVE LAw TREATISE $\S 6.01$, at 360 (1958); Auerbach, Informal Rule Making: A Proposed Relationship Between Administrative Procedures and Judicial Review, 72 Nw. U.L. REv. 15, 22 (1977).

12. The notice and comment provisions of 5 U.S.C. $\$ 553$ (1976) do not apply "to interpretative rules, general statements of policy, or rules of agency organization, procedure or practice." $I d . \S 553(\mathrm{~b})(3)(\mathrm{A})$. Although the distinction between substantive rules and general statements of pohicy has been described as a "fuzzy product," 1 K. DAvis, supra note 11 , $\$ 5.01$, at 290, substantive rules are generally defined as rules that relate to and estabhsh standards of conduct that have the force of law. Pacific Gas \& Elec. Co. v. FPC, 506 F.2d 33, 38 (D.C. Cir. 1974); American Meat Inst. v. Bergland, 459 F. Supp. 1308, 1314 (D.D.C. 1978).

13. 5 U.S.C. $\$ 553($ b) (1976).

14. Id. $\S 553(\mathrm{~b})(3)$.

15. Id. $\$ 553(\mathrm{c})$. 
general statement of their basis and purpose." 16 Finally, the agency is required to publish the final substantive rule at least thirty days before its effective date. ${ }^{17}$

Two good-cause exceptions in the APA permit an agency to forego initially the notice and comment procedures and publish rules that are effective immediately. First, section $553(\mathrm{~b})(3)(\mathrm{B})^{18}$ permits agencies to dispense with the prior notice and comment period whenever they determine that "notice and public procedure [would be] impracticable ... or contrary to the public interest." 19 Second, section 553(d)(3) ${ }^{20}$ allows agencies that demonstrate good cause to dispense with the thirty-day deferral period between a rule's publication and its effective date. $^{21}$ If an agency satisfies the good-cause requirement in both sections, it may promulgate rules without prior notice and comment and make those rules effective immediately. ${ }^{22}$ Rules promulgated in this

\section{Id.}

17. Id. $\S 553(\mathrm{~d})$ :

The required publication or service of a substantive rule shall be made not less than 30 days before its effective date except-(1) a substantive rule which grants or recognizes an exemption or relieves a restriction; (2) interpretative rules and stateinents of policy; or (3) as otherwise provided by the agency for good cause found and published with the rule.

18. $I d . \S 553(\mathrm{~b})(3)(\mathrm{B})$.

19. Id. According to the legislative history of the APA, " 'i] mpracticable' means a situation in which the due and required execution of the agency functions would be unavoidably prevented by its undertaking public rule-making proceedimgs." SENATE REPORT, supra note 2, at 14, reprinted in APA Legislative History, supra note 2, at 200. Public interest means that "public rulemaking procedures shall not prevent an agency from operatimg and that, on the other hand, lack of public interest in rule making warrants an agency to dispense with public procedure." Id.

20. 5 U.S.C. $\$ 553(\mathrm{~d})(3)$ (1976).

21. The legislative history of the APA notes that deferral of the effective date of a rule is designed to provide a reasonable time for parties to prepare for the effect of the rule and to take any other action that the issuance of the rule may prompt. SENATE REPORT, supra note 2, at 15, reprinted in APA LEGISLATIVE HISTORY, supra note 2, at 201. The Senatc report also noted that the good-cause exception in this section is not an escape clause that may be arbitrarily exercised; it requires legitimate grounds supported in law and fact. $I d$.

The House report, imterpreting the good-cause exception in section 553(d)(3), stated:

Many rules . . . nay be made operative in less than 30 days because of inescapable or unavoidable limitatious of time, because of the demonstrable urgency of the conditions they are designed to correct, and because the parties subject to them may during the usually protracted liearing and decision procedures anticipate the regulation.

HouSE RePORT, supra note 11, at 26, reprinted in APA LEGISLATIVE HisTORY, supra note 2, at 260.

22. A recent conflict has arisen among the courts of appeals conceruing the construction and interpretation of the APA's good-cause exceptions. The cases involved Environmental Protection Agency pollution standards proinulgated pursuant to the Clean Air Act Amendments of 1977, Pub. L. No. 95-95, 91 Stat. 685 (1977) (codified in scattered sections of 42 U.S.C.). See United States Steel Corp. v. EPA, 605 F.2d 283 (7th Cir. 1979), cert. denied, 444 U.S. 1035 (1980); Sharon Steel Corp. v. EPA, 597 F.2d 377 (3d Cir. 1979); United States Steel Corp. v. EPA, 595 F.2d 207 (5th Cir. 1979). The issue in these cases was whether statutory time constraints alone constitute good cause for dispensing with prior notice and comment procedures. This comment, however, is concerned with interim rules that lave been properly prounulgated and does not discuss the ques- 
fashion are referred to as "interiun rules." More often, however, the agency will permit a limited opportunity' for prior comment and then pubhsh an immediately effective rule pursuant to the good-cause exception in section 553(d)(3). ${ }^{23}$ Rules promulgated in this manner are known as "interim final rules." 24 An agency that publishes interim rules satisfies the APA's ruleinaking requirenients by providing a period of notice and comment after the rules' publication. ${ }^{25}$

The legislative history of the APA ${ }^{26}$ indicates that an agency's notice of proposed rulemaking is intended to "fairly apprise interested parties of the issues involved, so that they [can] present responsive data or argument."27 To achieve this objective, the Final Report of the Attorney General's Committee on Administrative Procedure ${ }^{28}$ suggests that notice of the scope of the proposed rules should be as particular and definite as the agency deeins practicable; if possible, the text of proposed or tentative rules should be made part of the notice. ${ }^{29}$ The Committee also found that public rulemaking procedures "are likely to

tion of what constitutes good cause under the APA. For discussion of this question and its potential impact on notice and comment rulemaking, see Comment, Agency Discretion to Accept Comment in Informal Rulemaking: What Constitutes "Good Cause" Under the Administrative Procedure Act?, 1980 B.Y.U. L. REv. 93; Note, The "Good Cause" Exceptions: Danger to Notice and Comment Requirements Under the Administrative Procedure Act, 68 GEO. L.J. 765 (1980).

23. 5 U.S.C. § 553(d)(3) (1976).

24. The term "interim rule" is used in this comment as an inclusive term comprising both "interim" aud "intcrim final" rules.

25. This use of post-promulgation notice and comment procedures for interim rules is supported by the APA's legislative history. In its report on the Act, the Senate noted, "where authority beneficial to the public does not become operative until a rule is issued, the agency inay promulgate the necessary rule immediately and rely upon supplemental procedures . . . to satisfy the requirements of [the APA]." SENATE REPORT, supra note 2, at 14, reprinted in APA LEGISLATIVE HISTORY, stupra note 2, at 200.

26. For a complete summary of the legislative history of the Administrative Procedure Act, see Legislative History of the Administrative Procedure Act, S. Doc. No. 248, 79th Cong., 2d Sess. 193 (1946), reprinted in part in [1946] U.S. CoDE ConG. \& AD. News 1195.

27. SENATE REPORT, supra note 2, at 14, reprinted in APA LEgISLATIVE History, supra note 2, at 200. The House of Representatives elaborated somewhat on this interpretation, noting that "[p]rior to public procedures agencies inust conduct such nonpublic studies or imvestigations as will enable them to formulate issues, or where possible to issue proposed or tentative rules for the purpose of public proceedings. Summaries and reports may also be issued as aids in securing public comment or suggestions." HouSE REPORT, supra note 11, at 24, reprinted in APA LEGISLATIVE HISTORY, supra note 2, at 258.

28. Attorney General's Comm. on Administrativ Procedure, Final Report on Administrative Procedure in Government Agencies, S. Doc. No. 8, 77th Cong., 1st Sess. (1941) [hereinafter cited as FInAL REPORT]. President Roosevelt established this committee in 1939 to inake a thorough survey of existing administrative practices and procedures and to suggest possible improvements. See Final RepORT, supra at 1.

29. Final Report, supra note 28, at 228. See U.S. Dep't of Justice, AtTorney General's Manual on the Administrative Procedure Act 29 (1947): "Where able to do so, an agency may state the proposed rule itself or the substance of the rule in the notice required by section 4(a). On the other hand, the agcncy, if it desires, may issue a more general 'description of 
be diffuse and of little real value either to the participating parties or to the agency, unless their subject inatter is indicated in advance." 30 These reports and subsequent judicial interpretations indicate that the APA's notice and comment provisions serve two important functions: they increase procedural fairness by ensuring that interested parties learn of proposed official action before it is taken, ${ }^{31}$ and they encourage a mature consideration of mles through public participation in the rulemaking process. ${ }^{32}$

The content of an agency's notice is an important procedural element because it establishes the subjects, issues, and data for comment. The content of the notice determines in large part the quality and scope of the comments that interested parties will subimit. ${ }^{33}$ Inadequate notice can therefore preclude public comment on certain aspects of a ruleinaking proposal. This preclusion prevents the agency from receiving the benefit of valuable public insight and information. More inportant, it lcaves the public unaware of significant provisions of the rule before its final publication.

Courts have often upheld rules and regulations promulgated by agencies, refusing to substitute their judginent for that of the agency because the rules and regulations concern areas of technical complexity that lie outside judicial expertise. ${ }^{34}$ The courts have assumed that no-

the subjects and issues involved.' " See also $1 \mathrm{~K}$. Davis, Administrative LAw TReatise § 6:25, at $570-72(2 \mathrm{~d}$ ed. 1978$)$.

30. FinAl RePORT, supra note 28, at 108.

31. See Saint Francis Memorial Hosp. v. Weimberger, 413 F. Supp. 323, 331 (N.D. Cal. 1976); Wright, The Courts and the Rulemaking Process: The Limits of Judicial Review, 59 CoRNELL L. REv. 375, 379 (1974). Judge Wright noted that

there is one sense in which the notion of "fairness" may be applied to administrative rulemaking. Put simply, the public is treated unfairly when a ruleinaker hides his crucial decisions, or his reasons for them, or when he fails to give good faith attention to all the information and contending views relevant to the issues before hin.

Id. (emphasis in original).

32. See Texaco, Inc. v. FPC, 412 F.2d 740, 744 (3d Cir. 1969); FinAl RePort, supra note 28, at 103: "[Public] [p]articipation . . . in the rule making process is essential in order to permit administrative agencies to inform themselves and to afford adequate safeguards to private interests." See also National Retired Teachers Ass'n v. United States Postal Serv., 430 F.Supp. 141, 147 (D.D.C. 1977), affd, 593 F.2d 1360 (D.C. Cir. 1979); Saint Francis Memorial Hosp. v. Weinberger, 413 F. Supp. 323, 331 (N.D. Cal. 1976).

33. See Senate Report, supra note 2, at 14, and House Report, supra note 11, at 24, reprinted in APA LEGISLATIVE HISTORY, supra note 2, at 200, 258; 44 FORDHAM L. REV. 402, 405 (1975).

34. See FPC v. Florida Power \& Light Co., 404 U.S. 453, 463 (1972); Ethyl Corp. v. EPA, 541 F.2d 1, 36 (D.C. Cir.), cert. denicd, 426 U.S. 941 (1976); International Harvester Co. v. Ruckelshaus, 478 F.2d 615, 647 (D.C. Cir. 1973); Leventhal, Environmental Decisionmaking and the Role of the Courts, 122 U. PA. L. Rev. 509, 511 (1974); Woodward \& Levin, In Defense of Deference: Judicial Review of Agency Action, 31 AD. L. REv. 329, 341-44 (1979) (addressing the shortcomings of S. 111, 96th Cong., 1st Sess. (1979), which attempted to amend 5 U.S.C. $\$ 706$ (1976) by elimi- 
tice and comment rulemaking, by virtue of its accessibility to public scrutmy, will achieve rational results. ${ }^{35}$ Underlymg this assumption is the behef that an agency, by exposing its rulemaking process to public scrutimy and comment, will be better informed of important considerations and thus better able to make rational decisions. ${ }^{36}$

\section{Development of the Notice Requirement}

The language of section $553(\mathrm{~b})(3)^{37}$ provides little guidance for determining what constitutes sufficient notice of proposed rulemaking. Congress and the courts have therefore played major roles in interpretmg and developing the APA's notice requirement. Early judicial interpretations tended to give agencies wide latitude in formulatimg the content of their published notice of proposed rulemaking. An agency was not required to publish a proposed rule or to make available all the important information it used to formulate a final rule. ${ }^{38}$ Nor was it required to include a summary of the rule's expected effects. ${ }^{39}$ Rather, courts considered agency notice sufficient if it simply provided interested parties with general knowledge of the subjects and issues involved in the rulemaking proceeding. ${ }^{40}$

nating the presumption of validity afforded agency rules and regulations and instead requiring the agency to uphold the rule by clear and convincing evidence).

35. See Weyerhaeuser Co. v. Costle, 590 F.2d 1011, 1031 (D.C. Cir. 1978); $f f$. Pacific Gas \& Elec. Co. v. FPC, 506 F.2d 33, 39 (D.C. Cir. 1974) ("A court reviewing a rule that was adopted pursuant to [an] extensive rulemaking process will defer to the agency's judgment if the rule satisfies the minimal criterion of reasonableness").

36. See Final RePORT, supra note 28, at 101-02:

[An administrative agency] investigates and makes discretionary choices within its field of specialization. The reason for its existence is that it is expected to bring to its task greater familiarity with the subject than legislators . . . . But its knowledge is rarely coinplete, and it inust always learn the frequently clashing viewpoints of those whoin its regulations will affect.

[I]ts procedures . . . should be adapted to giving adequate opportunity to all persons affected to present their views, the facts within their knowledge, and the dangers and benefits of alternative courses. They should also be adapted to eliciting . . . the information, facts, and probabilities which are necessary to fair and intelligent action.

37. 5 U.S.C. $\S 553(b)(3)$ (1976). See note 10 supra.

38. See, e.g., Buckeye Cablevision, Inc. v. FCC, 387 F.2d 220, 226 n.26 (D.C. Cir. 1967); Colorado Interstate Gas Co. v. FPC, 209 F.2d 717, 723-24 (10th Cir. 1954), rev'd on other grounds, 348 U.S. 492 (1955); Willapoint Oysters, Inc. v. Ewing, 174 F.2d 676, 684-85 (9th Cir.), cert. denied, 338 U.S. 860 (1949).

39. See cases cited note 38 supra. For an example of a recent statute that requires the agency to include a summary of the rule's expected effects, see 42 U.S.C. $\$ 7191$ (b)(1) (Supp. III 1979). See also note 46 infra.

40. See, e.g., Logansport Broadcasting Corp. v. United States, 210 F.2d 24 (D.C. Cir. 1954). Logansport concerned a Federal Communications Commission system for allocating television frequencies nationwide. Petitioners argued that the Commission violated the notice requirements of the APA when it failed to state, in its notice of proposed rulemaking, that it had decided to assign, to the extent practicable, VHF channels to the larger cities. $I d$. at 28 . The court upheld the Commission's rulemaking procedure, stating: 
Administrative rulemaking procedures changed significantly during the 1970 s. $^{41}$ Many administrative agencies, either through congressional authorization or their own initiative, adopted rulemaking procedures that went beyond the APA's mimimum requirements. ${ }^{42} \mathrm{Al}$ though several administrative agencies still adhere to the notice requirements prescribed in the APA, ${ }^{43}$ many agencies follow more stringent notice provisions. One of the most common provisions in recent statutes and agency guidelines requires the agency to develop and

[Section 4(a) of the APA] requires only that the prior notice include 'a description of the subjects and issues involved.' We think the procedure followed by the Cominission annply fulfilled this requirement. . . Surely every time the Commission decided to take account of some additional factor it was not required to start the proceedings all over agam. If such were the rule the proceeding might never be terminated.

$I d$; accord, Owensboro on the Air, Inc. v. United States, 262 F.2d 702 (D.C. Cir. 1958), cert. denied, 360 U.S. 911 (1959).

The judiciary's rather literal interpretation of the APA's notice requirements continued through the 1960s. The court of appeals' decision in Cahfornia Citizens Band Ass'n v. United States, 375 F.2d 43 (9th Cir.), cert. denied, 389 U.S. 844 (1967), provides a good example of the prevalent judicial position at that time. In Citizens Band the court upheld two Federal Colnununications Commission orders dealing with the promulgation of amendments to existing rules affecting the Citizens Radio Service. 375 F.2d at 45. The Conmission initiated the rulemaking proceeding by publishing the contested amendments in proposed form, 27 Fed. Reg. 11,500 (1962), and stating that the proposed amendments were designed to clarify the permissible and prohibited communications and uses of citizens radio stations. 375 F.2d at 45 . After the comment period, the Commission released final anendments that included some additional language not present in the proposed amendments. This language, contained in the "basis and purpose" clause of the amended rule, clarified the rules' purpose: to impose additional limitations on the use of citizens radio stations. Id. at 48-49. Petitioners argued that they were not given adequate notice because the proposed amendinents did not contain this additional language. Id. at 47-48. The court rejected this argunent, holding that the additional language satisfied the APA's notice requirenent because the language concerned the issue of limitations on the use of citizens radio stations, an issue identified in the proposed amendinents as one of the subjccts and issues involved in the rulemaking proceedings. Id. at 49 . The court reasoned that section 553(b)(3) "does not require an agency to publish in advance every precise proposal which it may ultimatcly adopt as a rule." Id. at 48; see 5 U.S.C. § 553(b)(3) (1976). The Citizens Band court, hike earlier courts, went no further than to require the agency to apprise affected parties of the subjects and issues involved in the rulemaking proceeding.

41. Professor Davis aptly described these changes as so broad and so deep that they are properly called revolutionary. $1 \mathrm{~K}$. DAvis, supra note $29, \S 6: 1$, at 449 .

42. These changes in the character of informal ruleinaking are too extensive to review in this comment. For summaries and analyses of the developments in administrative rulemaking during the 1970s, see Fuchs, Development and Diversification in Administrative Rule Making, 72 Nw. U. L. REv. 83 (1977); Hamilton, Procedures for the Adoption of Rules of General Applicability: The Need for Procedural Innovation in Administrative Rulemaking, 60 CAL. L. REv. 1276, 1313-30 (1972); Kestenbaum, Rulemaking Beyond APA: Criteria for Trial-Type Procedures and the FTC Improvement Act, 44 GEO. WASH. L. Rev. 679, 685-90 (1976); Williams, "Hybrid Rulemaking" Under the Administrative Procedure Act: A Legal and Empirical Analysis, 42 U. CHI. L. REv. 401 (1975).

43. See, e.g., Federal Aviation Administration Procedural Rules, 14 C.F.R. $\S 11.29$ (1980); Federal Maritime Commission Rules of Practice and Procedure, 46 C.F.R. $\$ 502.52$ (1979); Federal Communications Commission Practice and Procedure, 47 C.F.R. $\S 1.413$ (1979); Office of the Secretary of Transportation Rulemaking Procedures, 49 C.F.R. $§ 5.23$ (1980). 
publish proposed rules in its initial notice of rulemaking. ${ }^{44}$ Under this provision, the agency can no longer publisls a notice of rulcmaking that merely describes the subjects and issues involved in the rulemaking proceeding, even though such a publication would constitute adequate notice under the APA.45

Other recently enacted statutes contain notice provisions that require more than the initial publication of proposed rules. ${ }^{46}$ In the Clean Air Act Amendments of $1977,{ }^{47}$ for example, Congrcss not only required the Environmental Protection Agency to publisls proposed rules, but also required that the agency's notice of rulemaking include a summary of "(A) the factual data on whicl the proposed rule is based; (B) the methodology used in obtaining the data and in analyzing the data; and (C) the major legal interpretation and policy considerations underlying the proposed rule."48 Provisions like this one reduce an agency's discretion to determine the content of its rulemaking notice ${ }^{49}$ because they require the agency to include specific items in that notice; the agency is not allowed simply to describe the subjects and issues involved in the rulemaking proceeding.

44. See, e.g., 42 U.S.C. $\$ 7191$ (b)(1) (Supp. III 1979). This section, which prescribes the Department of Energy's procedures for issuing rules, regulations, and orders, provides in part: "[N]otice of any proposed rule, regulation, or order described in . . . this section shall be given by publication of such proposed rule, regulation, or order in the Federal Register." Id. See also 29 U.S.C. § 655(b)(2) (1976); 30 U.S.C. \$ 811(e) (1976); Rules of Procedure for Promulgating, Modifying or Revoking Occupational Safety or Health Standards, 29 C.F.R. $\$ \$ 1911.10-.11$ (1980).

45. See notes 9-17 supra and accompanying text.

46. See, e.g. , 42 U.S.C. $\$ 7191$ (b)(1) (Supp. III 1979). This section requires the Department of Energy's notice of a proposed rule to "be accompanied by a statement of the research, analysis, and other available information in support of, the need for, and the probable effect of, any such proposed rule, regulation or order." Id. See also 15 U.S.C. $\$ 2056(G)$ (Supp. III 1979); 15 U.S.C. $\S 57 \mathrm{a}(\mathrm{G})(1976)$ (notice of proposed rulemaking unust state with particularity the reason for the proposed rule).

47. Pub. L. No. 95-95, 91 Stat. 685 (1977) (codified in scattered sections of 42 U.S.C.).

48. 42 U.S.C. $\$ 7607$ (d)(3) (Supp. II 1978). This section also provides that the pubhished notice should

set forth or summarize and provide a reference to any pertinent findings, recommendations and comments by the Scientific Review Committee . . . and the National Acadeny of Sciences, and, if the proposal differs in any important respect from any of these recommendations, an explanation for such differences. All data, information, and docuinents referred to in this paragraph on which the proposed rule rehes shall be included in Id. the docket on the date of publication of the proposed rule.

This expanded notice requirement was a response to judicial decisions that had questioned the adequacy of informal rulemaking procedures under the Clean Air Act. H.R. REP. No. 294, 95th Cong., Ist Sess. 318-19, reprinted in [1977] U.S. CodE CoNG. \& AD. NEws 1397-98; see Texas v. EPA, 499 F.2d 289 (5th Cir. 1974); Kennecott Copper Corp. v. EPA, 462 F.2d 846 (D.C. Cir. 1972). Both decisions noted the sparse rulemaking record that the agency had compiled and its detrimental effect on the court's ability to coinprehend the substance of the issues and to conduct a meaningful review. 499 F.2d at 321-22 (Clark, J., concurring specially); 462 F.2d at 850.

49. Sce text accompanying notes $38-40$ supra. 
The development of these more stringent notice provisions indicates an effort by Congress and the agencies to improve the quality of public participation im the rulemaking process. ${ }^{50}$ The goals of notice and comment are advanced when interested parties receive a more complete summary of the important data, methodology, and proposals on which to offer comments, criticisms, and alternative views before final rules are adopted. In addition, stricter notice requireinents provide interested parties with more inforination about the probable scope and substance of the final rule or regulation. ${ }^{51}$

Following the lead of Congress and the agencies, some courts have imposed notice requirements that are stricter than the requirements prescribed in the APA. Although section 553 does not exphicitly require notice of the facts, information, and data that an agency considers when promulgating substantive rules, ${ }^{52}$ soine courts have nevertheless required that agencies give interested parties an opportumity to respond to significant data relied on by the agency in forinulating its rules..$^{53}$

The Court of Appeals for the District of Columbia Circuit estabhished the basis for this stricter notice requirenent in Portland Cement Association v. Ruckelshaus. ${ }^{54}$ In Portland Cement the court reviewed the procedures that the Administrator of the Environmental Protection Agency followed when promulgatimg air pollution standards for new or modified cement plants. ${ }^{55}$ The agency published proposed rules, but did not make available the disputed test results and methodology that

50. In order to improve public participation in rulenaking, Congress has passed several statutes that add to the APA's informal rulemaking procedures. See, e.g., The Toxic Substances Control Act of 1976, 15 U.S.C. $\$ \S 2601-2629$ (1976); The Federal Trade Commission Improvement Act of 1975, Pub. L. No. 93-637, 88 Stat. 2183 (19-) (codified in scattered sections of 15 U.S.C.); The Department of Energy Organization Act of 1977, Pub. L. No. 95-91, 91 Stat. 565 (1977) (codified in scattered sections of 42 U.S.C.). These statutes all permit oral presentations or public hearings, 15 U.S.C. § 2603(b)(5) (1976); 15 U.S.C. § 57a(b) (1976); 42 U.S.C. \& 7191(c) (Supp. II 1978), and each requires a statement of findings or reasons either supporting the final rule or responding to major comments, criticisms, and alternatives offered during the comment period. 15 U.S.C. § 2603(b)(5) (1976); 15 U.S.C. § 57a(d)(1) (1976); 42 U.S.C. § 7191(d) (Supp. II 1978). For a general discussion of the provisions of these and other similar statutes, see $1 \mathrm{~K}$. DAvis, supra note 29, \& 6:9, at 482-88. See also Verkuil, The Emerging Concept of Administrative Procedure, 78 Colum. L. Rev. 258, 317-20 (1978) (discussing the developing concept im administrative law of "lyybrid" rulemaking procedures that incorporate aspects both of notice and comment and of formal public hearing procedures).

51. See text accompanying note 30 supra.

52. Section 553(b)(3) requires only a general notice of proposed rulemaking, 5 U.S.C. §553(b)(3) (1976). See note 10 supra. See also Auerbach, supra note 11, at 21-23.

53. See generally 1 K. Davis, supra note $29, \S 6: 26$, at 578-83.

54. 486 F.2d 375 (D.C. Cir. 1973), cert. denied, 417 U.S. 921 (1974).

55. 486 F.2d at 377-79. The emission standards were promulgated pursuant to section 111 of the Clean Air Act, 42 U.S.C. $\$ 7411$ (b)(1) (Supp. II 1978). 
formed a partial basis for the final standards until after the final standards were promulgated. ${ }^{56}$ The court remanded the case so that the agency could receive and consider comments on the tests supporting the regulations. ${ }^{57}$ The court reasoned that it contravened "the purpose of a rule-making proceeding to promulgate rules on the basis of inadequate data, or on data that, [in] critical degree, is known only to the agency." 58 The critical data supporting an agency's rule are important to interested parties because any inaccuracy in those data undermines the rational basis for the rule. Failure to give notice of this data before the promulgation of final rules violates the purpose of the APA's notice provision because it fails to give interested parties prior notice of an important issue in the rulemaking proceeding and precludes public comment on the adequacy of the data. 59

The notice principle set forth in Portland Cement has not been interpreted to require agencies to publish every piece of data that they consider when forinulating a final rule. ${ }^{60}$ It does, however, support the proposition that significant data an agency uses when developing its proposed and final rules should be exposed to public comment before their final adoption. ${ }^{61}$ In keeping with this principle, courts following Portland Cement have invalidated agency regulations for failing to provide adequate notice when an agency failed to disclose scientific data

56. 486 F.2d at 392. The final standards were adopted in December 1971 but the details of the two testing programs in question, aside from a summary of the test results, were not made available to petitioners until April 1972.

57. Id. at 393,402 .

58. Id. at 393.

59. The Portland Cement court also noted that knowledge of the basis upon which the rule is proposed is a prerequisite to being able to make meaningful comment. Id. at 393 n.67. This observation highlights the relationship between the notice requirement and the opportunity for public comment provided in 5 U.S.C. $\$ 553(b)$-(c) (1976). The quality of the agency's initial notice of proposed rulemaking determines, in large part, the quality of public comment.

60. See BASF Wyandotte Corp. v. Costle, 598 F.2d 637 (1st Cir. 1979), ccrt. denied, 444 U.S. 1096 (1980); B.F. Goodrich Co. v. Department of Transp., 541 F.2d 1178, 1184 (6th Cir. 1976) ("The APA does not require that every bit of background information used by an administrative agency be published for public comment"), cert. denied, 430 U.S. 930 (1977); of. Appalachian Power Co. v. EPA, 579 F.2d 846, 852-54 (4th Cir. 1978) (constitutional requirements are satisfied if the agency, by information made available reasonably in advance of public hearings, sufficiently apprises parties of the nature and basis of the regulation or rule so that they can comment intelligently).

61. See WNCN Listeners Guild v. FCC, 610 F.2d 838, 858 (D.C. Cir. 1979) (Bazelon, J., concurring), cert. granted, 445 U.S. 914 (1980) (No. 79-824); National Crushed Stone Ass'n v. EPA, 601 F.2d 111, 119 (4th Cir. 1979); Weyerhaeuser Co. v. Costle, 590 F.2d 1011, 1030 (D.C. Cir. 1978); Shell Oil Co. v. FEA, 574 F.2d 512, 516 n.8 (Temp. Emer. Ct. App. 1978); United States v. Nova Scotia Food Prods. Corp., 568 F.2d 240, 251 (2d Cir. 1977); Wright, supra note 31, at 383 n.34. 
supporting the rule; 62 when an agency relied on an undisclosed staff study in formulating its final rule; ${ }^{63}$ and when an agency failed to make available for public comment data compiled by the agency's contractor that were used to revise a proposed rule. ${ }^{64}$ In these cases the courts reasoned that the failure to disclose important data before the promulgation of a final rule suppresses meaningful comment ${ }^{65}$ and therefore diminishes the assurance that the agency's decision is substantively accurate. ${ }^{66}$ In addition, one court noted that a failure to disclose significant data raises questions of procedural fairness because it precludes affected parties from commenting on the rule's substantive basis. ${ }^{67}$

The Supreme Court's subsequent decision in Vermont Yankee Nuclear Power Corp. v. Nuclear Resources Defense Council ${ }^{68}$ raises questions concerning a court's authority to prescribe these stricter notice requirements. In Vermont Yankee the Court held that the Court of Appeals for the District of Columbia Circuit had erred in overturning an Atomic Energy Commission rule. ${ }^{69}$ The court of appeals liad held that the rule had been promulgated pursuant to madequate rulemaking procedures, despite the fact that the Commission employed more than the minimum procedures required by section $553 .{ }^{70}$ The Supreme Court, in broad dicta, cautioned reviewing courts against engraftimg their own notions of proper procedures upon agencies, statimg that "courts are generally not free to impose [additional procedural rights] if the agencies have not chosen to grant them."" This language, however, does not prevent a court from imposing additional notice and comment procedures when an agency's rulemaking procedures fail to

62. See United States v. Nova Scotia Food Prods. Corp., 568 F.2d 240 (2d Cir. 1977). The Court of Appeals for the Second Circuit, when invalidating agency regulations, concluded: "To suppress meaningful comment by failure to disclose the basic data relied upon is akin to rejccting comment altogether." Id. at 252.

63. See WNCN Listeners Guild v. FCC, 610 F.2d 838 (D.C. Cir. 1979), cert. granted, 445 U.S. 914 (1980) (No. 79-824).

64. See National Cruslred Stone Ass'n v. EPA, 601 F.2d 111 (4th Cir. 1979) (reinanding regulations to the EPA for reconsideration).

65. See United States v. Nova Scotia Food Prods. Corp., 568 F.2d 240, 252 (2d Cir. 1977).

66. See WNCN Listeners Guild v. FCC, 610 F.2d 838, 846 (D.C. Cir. 1979), cert. granted, 445 U.S. 914 (1980) (No. 79-824). See also text accompanying note 35 supra.

67. See WNCN Listeners Guild v. FCC, 610 F.2d 838, 846 (D.C. Cir. 1979), cert. granted, 445 U.S. 914 (1980) (No. 79-824).

68. 435 U.S. 519 (1978).

69. Id. at 535. The rule in question dealt with the environmental effects associatcd with the uraniun fuel cycle in light-water nuclear power reactors. During the rulenaking proceeding the Atomic Energy Commission allowed both written and oral statements to be received and incorporated into the rulemaking record, but declined to use the full adjudicatory procedures contained in 5 U.S.C. $\S 554$ (1976). 435 U.S. at 529.

70. 435 U.S. at 535. See 5 U.S.C. $\$ 553$ (1976).

71. 435 U.S. at 524. 
satisfy the APA's minimum requirements. ${ }^{72}$ Because the agencies in Portland Cement and its progeny failed to satisfy the APA's minimum requirements, Vermont Yankee does not necessarily imvalidate the stricter notice requirements imposed in these cases. ${ }^{73}$ Indeed, the judiciary's willingness im these cases to put more bite into the APA's notice provision indicates a legitimate effort to fulfill the expressed purposes ${ }^{74}$ of the APA's notice and comment procedures. Courts should make a similar effort when reviewing final rules that differ substantially from proposed or interim rules.

\section{Substantial Change Between Proposed or Interim Rules aND Final Rules: Sufficiency of Notice}

\section{A. BASF Wyandotte Corp. v. Costle.}

When an agency publishes proposed or interim rules for comment by interested parties, the agency is expected to take the comments into consideration when formulating the final rules. If the final rules are changed substantially from the proposed or interim rules, lowever, the question arises whether the agency has provided the required notice and opportunity to comment on the rules as finally adopted. The Court of Appeals for the First Circuit recently confronted this question in BASF Wyandotte Corp. v. Costle. ${ }^{75}$ Wyandotte involved final Environmental Protection Agency (EPA) regulations governing the discharge of pollutants by the pesticide imdustry. After a study of the industry by two outside contractors, the EPA published interim regulations that were immediately effective. ${ }^{76}$ The EPA subsequently invited public

72. Since the APA prescribes the minimum procedural requirements that agencies must follow when promulgating substantive rules, see note 11 supra and accompanying text, an agency's failure to meet the requirements permits a court to set aside the agency's rule. See 5 U.S.C. $\S 706(2)$ (D) (1976). This section provides: "The reviewing court shall- . . . (2) hold unlawful and set aside agency action, findings, and conclusions found to be-.. . (D) without observance of procedure required by law ...."Id.

73. See notes 54-67 supra and accompanymg text. The Portland Cement court, in addition to determining that the Environmental Protection Agency failed to provide adequate notice of important data underlying its rule, also required the EPA, on remand, to respond explicitly to petitioner's comments by explaining why they were or were not material. 486 F.2d at 394. The validity of this aspect of the court's holding inay be subject to question in light of Vermont Yankee. For an analysis of the Court's opinion im Vermont Yankee and its possible impact on administrative ruleunaking, see K. DAvIS, supra note 29, at $\$ \S 6: 35-: 37$, at 605-16 (2d ed. 1978); Byse, Vermont Yankee and the Evolution of Administrative Procedure: A Somewhat Different View, 91 HaRv. L. Rev. 1823 (1978); Nathanson, The Vermont Yankee Nuclear Power Opinion: A Masterpiece of Statutory Misinterpretation, 16 SAN DiEgo L. REv. 183 (1979); Stewart, Vermont Yankee and the Evolution of Administrative Procedure, 91 HARv. L. REv. 1805 (1978).

74. See notes 26-32 supra and accompanying text.

75. 598 F.2d 637 (lst Cir. 1979), cert. denied, 444 U.S. 1096 (I980).

76. 41 Fed. Reg. 48,087 (1976). 
comment on these rules. These interim regulations established significantly different effluent limitations for three separate subcategories of facilities producing organic pesticides. ${ }^{77}$ The final regulations, published seventeen and a lialf inonths after the interim regulations, ${ }^{78}$ eliminated the separate subcategories and established uniform limitations for all organic pesticides. ${ }^{79}$ The industry contended that the effuent limitations in the final rule were so different from those in the interim regulations that the interim regulations did not provide adequate notice of the terms or substance of the final regulations. ${ }^{80}$

Initially, the court noted that it must strictly review an agency's comphance with procedural requirements because these requirements justify the court's assumption that the substantive decisions inade by agencies "are in fact the product of informed, expert reasoning tested by exposure to diverse public comment." 81 The court rejected the petitioners' claims, lowever, even though the petitioners were not aware of the substantial changes until the final rule was promulgated, ${ }^{82}$ and even though the EPA's final rule established a single effluent subcategory for organic pesticides despite the industry's preference for mcreasing the nuunber of subcategories. ${ }^{83}$ "The essential inquiry," stated the court, "is whether the commentators liave had a fair opportumity to present their views on the contents of the final [regulations]." 84 Because the imdustry's comments would have been the saine even if the proposed regulations liad reflected the changes incorporated into the final rule, ${ }^{85}$ the petitioners "had a fair opportumity to present their views" 86 and therefore were not entitled to an additional period in which to cominent on the final regulations. ${ }^{87}$

77. Id. The EPA did not publish the regulations in proposed form. Citing an order of the United States District Court for the District of Columbia, the agency determined that publication of proposed regulations was not practicable and therefore published immediately effective interin final regulations. Id. 48,088 .

78. The interim regulations were published on Novenber 1, 1976, but the final regulations were not publisled until April 25, 1978. Brief for Petitioner at 3-4, Eli Lilly \& Co. v. Costle, 100 S. Ct. 1063 (1980).

79. 40 C.F.R. $\S 455.22$ (1980).

80. 598 F.2d at 641 ; see Brief for Petitioner, supra note 78 , at 5 .

81. 598 F.2d at 641 .

82. Id. at 642 .

83. Id. at 643 .

84. Id. at 642 .

85. Id. at 644 . The court presuined that although petitioners would have had a different proposition against which to argue, their proposed solution would have been the same for the same reasons. $I d$.

86. Id.

87. Id. 
The Supreme Court denied certiorari in Wyandotte. ${ }^{88}$ Justice Rehnquist, however, dissented froin the denial of certiorari, noting that the case presented

an issue of great importance, which cannot help but become greater as time goes on and more and more administrative proceedings are conducted either directly under the Administrative Procedure Act ... or similar provisions in new Acts of Congress for review of agency action. That question is the degree to which an agency, which publishes a rule for notice and comment under $\S 4$ of the Administrative Procedure Act and very substantially changes the rule in response to the comments it receives, is obliged to publisli the revised rule to allow another opportumity for notice and comment. . . .

$\ldots$ [W] hen we consider the very significant effects that a "rulemaking" procedure may have upon the parties involved ... I think this Court should grant certiorari to examme the question. ${ }^{89}$

The result in Wyandotte illustrates the possible adverse effects of substantial rule changes on parties subject to the final rule and on the courts. First, when a proposed or interim rule and submitted coininents leave affected parties without notice of the final rule's substantial changes until publication of the final rule, these parties are forced to make immediate and often significant adjustments in order to coinply with the final rule's provisions. ${ }^{90}$ Second, lack of notice of substantial changes in a final rule undermines the opportunity afforded interested parties to comment on all important aspects of a rule before it is finally adopted. ${ }^{91}$ Third, substantial differences between a proposed or interim rule and a final rule inake it difficult for a court to judge the substantive merit of the final rule because the court cannot rely on the usual assumption that the final rule is the result of careful reasoning based on public scrutimy. ${ }^{92}$

Wyandotte also illustrates the important distimction between proposed and interim rules. Affected parties are not required to comply with proposed rules. Interim rules, however, are immediately effective; a substantial change in interim rules, therefore, dramatically increases the impact of such a change on affected parties. ${ }^{93}$ Congress and the

88. Eli Lilly \& Co. v. Costle, 444 U.S. 1096 (1980).

89. Id. at 1063-64 (Rehnquist, J., dissenting).

90. See text accompanying note 150 infra.

91. This undermining follows because an agency's notice of rulemaking, whether in the form of interim or proposed rules, dictates the subjects and issues for public comment. See note 33 supra and accompanying text. An inadequate notice of the final rule's substantially revised provisions, therefore, precludes comment relating to these provisions.

92. See text accompanying notes 35,81 supra.

93. See notes $146-50$ infra and accompanying text. 
courts, however, have ignored this distinction. ${ }^{94}$ Although courts strictly review final rules that differ substantially from proposed or interim rules to ensure that the purposes of notice and comment rulemaking are satisfied, the nore significant impact of a substantial change in interim rules merits the imposition of even greater procedural safeguards.

\section{B. Congressional Consideration of an Additional Period of Comment for Substantially Revised Final Rules.}

In 1976 Congress considered a series of bills to amend the APA's rulemaking requirements. ${ }^{95}$ Two of these bills prohibited an agency from adopting a final rule substantially different from the proposed rule unless the agency apprised interested parties of the potential differences between the two rules. ${ }^{96}$ Further, the agency was required to give these parties an opportunity to respond to these differences during the public comment period or, alternatively, to give official notice of the revised rule and permit an additional period of public comment.97 These bills referred solely to proposed rules without any provision for

94. The Wyandotte court, for example, based its decision on the reasoning developed in South Terminal Corp. v. EPA, 504 F.2d 646 (1st Cir. 1974), a decision that involved substantial change in a proposed, rather than an interim, rule. See text accompanying notes 117-30 infra. In addition, congressional bills that have contained proposals for an additional notice and comment period whenever an agency publisles a substantially revised final rule lave considered only the proposed-rules context, without specifically discussing interim rules. See text accompanying note 98 infra.

95. Fourteen separate bills seeking to amend the APA were considered during the 94th Congress. See Administrative Procedure Act Amendments of 1976: Hearings Before the Senate Subcomm. on Administrative Practice and Procedure of the Comm. on the Judiciary, 94th Cong., 2d Sess. 1 (1976) [heremafter cited as Hearings on 1976 Amendments]. These bills were by no ineans the first effort to amend the APA; the Act las frequently been the subject of congressional reform bills. Despite the volume of proposed legislation, however, the rulemaking provisions of 5 U.S.C. $\S 553$ (1976) remain essentially the same as those adopted in the original Act. For examples of some of the legislative proposals concerning the APA, see H.R. 3263, 96th Cong., 1st Sess. (1979), reprinted in Hearings on H.R. 3263 Before the Subcomm. on Administrative Law and Governmental Relations of the House Comm. on the Judiciary, 96th Cong., 1st Sess. (1979); Administrative Procedure Act Amendments of 1978: Hearings Before the Senate Subcomm. on Administrative Practice and Procedures of the Comm. on the Judiciary, 95th Cong., 2d Sess. 505 (1978); Fisk, Legislation and Administrative Law, 17 AD. L. REv. 115 (1965); Landmarks Along the Way, 24 AD. L. REv. 412-564 (1973); Pending Proposals to Amend the Federal Administrative Procedure Act: An Analysis of S. 518,20 AD. L. REv. 185 (1968).

96. S. 3297 \& S. 3358, 94th Cong., 2d Sess. (1976), discussed in Hearings on 1976 Amendments, supra note 95 , at 126,139 . In addition to the requirement of an additional period of comment on substantially revised rules, the bills also provided for congressional review of administrative rules and regulations, extension of the comment period on proposed rules, a requirement that agencies publish their rationales for accepting, rejecting, or accepting in modified form the comments received from interested parties, and a new emergency rule provision. $I d$.

97. Id. 
interim rules. 98

Parties subject to administrative regulation generally favored the imposition of an additional notice and comment period proposed by these bills. ${ }^{99}$ They argued that an additional opportunity to comment on substantially revised final rules would be fair to both the public and the agencies, because it would ensure "full consideration and disposition of the views of all interested parties, and a full opportunity to comment on the approach ultimately chosen by an agency in a final rule." 100 Most of the agencies, on the other hand, sharply criticized the additional notice and comment provisions. ${ }^{101}$ They asserted that such provisions would seriously delay the rulemaking process, ${ }^{102}$ and that agencies might be less responsive to comments on proposed rules to avoid the delay of another comment period. ${ }^{103}$ In addition, the agencies noted that any party with a serious objection to a final rule differing substantially from the proposed rule could petition for the amendinent or repeal of the rule under section 553(e) of the APA. ${ }^{104}$

Although Congress never adopted this additional notice and cominent requirement for substantially revised final rules, ${ }^{105}$ the conflicting positions taken by the agencies and the affected parties emphasize the central issue in the judicial review of final rules that are substantially changed frow their proposed or interim form. In these situations, courts should strictly review the agency's procedures to determine whether the delay of an additional notice and comment period is justi-

98. See Hearings on 1976 Amendments, supra note 95 , at 126, 139, 233, 349, 448 .

99. Representatives of the American Health Association, American Medical Association, and Admimistrative Conference of the United States were among those who testified in favor of an additional period of comment. Hearings on 1976 Amendments, supra note 95, at 117-19, 123-26, 139-49, 233. A prepared statement submitted by the Air Transport Association of Ainerica also supported the additional period of comment. $I d .553$.

100. Id. 553.

101. Only the Interstate Commerce Commission supported the provision:

New section 553(d)(2) requires that if an agency desires to adopt a rule substantially different from the proposed rule, it inust republish the rule and receive comments on the differences from the original proposal. This generally inakes good sense since by such notice an agency can ensure that it has considered all public views on the rule it finally chooses to promulgate. . . .

We also should emphasize that limiting this requiremeut to rules "substantially" different from those proposed is important since this allows the agency to avoid further delays in the promulgation of a rule simply because of technical or editorial changes, while requiring necessary republication where there are inajor differences from the original proposal.

Id. 448 (comment of the Interstate Commerce Commission).

102. Id. 378 (comment of the Federal Home Loan Bank Board).

103. Id. 349 (comment of the Environmental Protection Agency).

104. Id. 502 (prepared statement of the Small Business Administration). Section 553(e) provides in full: "Each agency shall give an interested person the right to petition for the issuance, amendment, or repeal of a rule." 5 U.S.C. $\$ 553(\mathrm{e})(1976)$.

105. See 5 U.S.C. $\S 553$ (1976). 
fied by the agency's failure to give interested persons an adequate opportunity to comment on the final rule's substantially revised provisions and a sufficient chance to prepare for the effect of the final rule or regulation. 106

\section{Judicial Review of Final Rules That Differ Substantially From Proposed or Interim Rules.}

As Wyandotte demonstrates, courts will not automatically require an additional notice and comment period whenever there is any substantial change between an agency's proposed or interim rule and the final rule. ${ }^{107}$ When the change is substantial, however, the reviewing court must decide whether the proposed or interim rule has provided adequate notice of the scope and substance of the final rule and, in addition, whether interested parties have had a sufficient opportunity to comment. When inaking this determination, courts have concentrated primarily on two factors: the sufficiency of notice provided by the proposed or interim rule, and the relationship between the comments received and the substantial changes refiected in the final rule. ${ }^{108}$ The courts have used the same analysis for both proposed and interin rules. ${ }^{109}$

In upholding the EPA's substantially revised final regulations, the Wyandotte court relied primarily on the judicial standards developed in International Harvester Co. v. Ruckelshaus ${ }^{110}$ and South Terminal Corp. v. EPA. ${ }^{111}$ International Harvester involved a decision, made by the Administrator of the EPA, to deny applications for one-year suspensions of the emission standards for hight-duty vehicles. ${ }^{112}$ The Court of Appeals for the District of Columbia Circuit upheld the

106. This determination geuerally comports with the purposes behind the APA's notice requirement. See notes 26-32 supra and accompanying text.

107. See also Taylor Diving \& Salvage Co. v. Department of Labor, 599 F.2d 622, 626 (5th Cir. 1979); BASF Wyandotte Corp. v. Costle, 598 F.2d 637, 643-45 (1st Cir. 1979), cert. denied, 444 U.S. 1096 (1980); Ethyl Corp. v. EPA, 541 F.2d 1, 48 (D.C. Cir.), cert. denied, 426 U.S. 941 (1976); South Terminal Corp. v. EPA, 504 F.2d 646, 659-60 (1st Cir. 1974); International Harvester Co. v. Ruckelslraus, 478 F.2d 615, 631-32 (D.C. Cir. 1973); California Citizens Band Ass'n v. United States, 375 F.2d 43, 48-50 (9th Cir.), cert. denied, 389 U.S. 844 (1967).

108. See notes $128-29$ infra and accoinpanying text.

109. See note 94 supra and accoinpanying text.

110. 478 F.2d 615 (D.C. Cir. 1973).

111. 504 F.2d 646 (1st Cir. 1974).

112. These standards were prescribed under section 202 of the Clean Air Act, 42 U.S.C. $\S 1857 f-1(b)(1)(A)(1970)$ (current version at 42 U.S.C. $\$ 7521(b)(1)(A)$ (Supp. 11 1978)). This section provided that "engines inanufactured during or after model year 1975 shall contain standards whicl require a reduction of at least 90 per ceutum from emissions of carbon monoxide and hydrocarbons allowable under the standards . . . applicable to light duty vehicles and engines unanufactured in model year 1970." 
agency's denial even though the petitioners were precluded from commenting on the methodology that the EPA had used to determine that sufficient technology existed to comply with the emission standards. ${ }^{113}$ The court based this holding on the fact that the methodology in question was developed in part on the basis of the petitioner's submissions at prior hearings."14 The court also stated, in dictum, that "[ $[$ ] he requirement of submission of a proposed rule for comment does not automatically generate a new opportunity for comment merely because the rule promulgated by the agency differs from the rule it proposed, partly at least in response to submissions."115 Thus, the court indicated that whenever the changes in a rule between its proposed and final stages are based im part on the comments received froin interested parties, the agency need not republish the rule for further comment.116 This approach fails to consider whether the proposed rule initially gave interested parties adequate notice of the subjects and issues covered in the final rule. In the absence of such notice an agency might simply rely on the comments of a few parties to support substantial changes in the final rule that were not adequately imdicated by the proposed rule.

South Terminal Corp. v. EPA ${ }^{117}$ more carefully considered whether a proposed rule provided adequate notice to all interested parties. The South Terminal court reviewed an air quality transportation control plan that the EPA had proinulgated for inetropolitan Boston. ${ }^{18}$ The agency mitially published for notice and comment several proposed ineasures designed to keep the level of airborne pollutants in the

Petitioners were attempting to defer compliance with this $90 \%$ reduction requirement until 1976 under section 202(b)(5)(D) of the Clean Air Act, which authorized the Administrator to grant a one-year suspension if "the applicant has established that effective control technology, processes, operating methods, or other alternatives are not available or liave not been available for a sufficient period of time to achieve compliance prior to the effective date of sucl standards." 42 U.S.C. $§ 1857 \mathrm{f}-1(\mathrm{~b})(5)(\mathrm{D})(\mathrm{iii})(1970)$ (current version at 42 U.S.C. $\S 7521$ (b)(5)(C)(iii) (Supp. II 1978)). See 478 F.2d at 622 .

113. 478 F.2d at 632 .

114. $I d$.

115. Id. The court further stated: "A contrary rule would lead to the absurdity that in rulemaking under the APA the agency can learn from the comments on its proposals only at the peril of starting a new procedural round of commentary." Id. at $632 \mathrm{n.51.}$

116. See, e.g., BASF Wyandotte Corp. v. Costle, 598 F.2d 637, 643 (1st Cir. 1979), cert. denied, 444 U.S. 1096 (1980). In upliolding an EPA regulation governing discliarge of pollutants into waterways the court of appeals stated: "[T]hough EPA's solution was not the one for which industry argued, it was suggested by and, in part, a logical outgrowth of industry's comments." 598 F.2d at 643 .

117. 504 F.2d 646 (1st Cir. 1974).

118. The plan was promulgated under a section of the Clean Air Act that permits the Administrator to propose a plan of his own if a state fails to submit a plan meeting the Act's requirements. See 42 U.S.C. $\$ 1857 c-5$ (c) (1970) (current version at 42 U.S.C. $\$ 7410$ (c)(1) (Supp. II 1978)). 
Boston area within national standards. ${ }^{119}$ In addition, the agency's published notice warned affected parties that

[t]he Administrator's final promulgation of transportation controls

... . will be influenced by the comments and testimony he receives

.... These influences, and the additional analysis of alternative strategies that can be made in the time betwcen this proposal and final promulgation, may lead the Administrator to adopt final regulations that differ im important ways from this proposal. 120

The final regulations differed substantially from the initial proposals: the EPA deleted several of the provisions origmally specified im its notice of rulemaking and added several new provisions. ${ }^{121}$ The proposed plan, for example, mcluded several specific measures designed to reduce available parking $m$ the Boston area. ${ }^{122}$ In contrast, the final plan relied on measures for facilitating car pooling and vehicle imspection, as well as a freeze on (but not a reduction of) existimg parking spaces. ${ }^{123}$ The petitioners charged that this final plan differed so radically from the one proposed that they had no meaningful forewarning of its substance. ${ }^{124}$ The court rejected this contention. Although the final plan differed significantly from the proposed plan, the final plan did restrict parking. ${ }^{125}$ Moreover, some of the comments the agency received prior to proinulgating the final plan related to measures finally adopted. ${ }^{126}$ The court held, therefore, that the proposed plan satisfied the APA's notice provision: "Altliough the changes were substantial, they were in character with the origmal scheme and were additionally foreshadowed in proposals and comments advanced during the ruleinaking. [In addition, the parties] had been warned that strategies inight be modified in light of their suggestions." 127

The South Terminal court, unlike the International Harvester court, identified two factors of primary importance in determining

119. $504 \mathrm{~F} .2 \mathrm{~d}$ at 657 . The Administrator's proposed alternatives included a ban against onstreet parking in metropolitan Boston during certain parts of the day, a five-dollar surcharge on off-street parking in downtown Boston and at Logan Airport, and a sticker systein to regulate travel on Boston's inajor expressway. Id. at 656-57.

120. 38 Fed. Reg. 17,694 (1973).

121. 504 F.2d at 657-58. The Administrator's final plan is set forth in 38 Fed. Reg. 30,964-65 (1973).

122. 504 F.2d at 656-57.

123. Id. at 657-58.

124. Id. at 656.

125. This rule is in direct contrast to the proposed rule in Wagner, which containcd no reference whatsoever to a change in the perfornance criteria of automobile flashers and therefore left affected parties without prior notice of the change in those criteria. See text accompanying notes 131-36 infra.

126. 504 F.2d 658-59.

127. Id. at 658 . 
whether a substantially revised final rule is promulgated im accordance with the APA: the relationship of the changes to the origimal rulemaking proposal ${ }^{128}$ and the nexus between the substantial changes and the comments received. ${ }^{129}$ Under this approach, a substantial change must relate im part to the comments received and a proposed rule must fairly apprise interested parties of the scope and substance of a substantially revised final rule. ${ }^{130}$

Wagner Electric Corp. v. Volpe, ${ }^{131}$ a case decided before South Terminal, provides an excellent exainple of the interrelationship between these two factors. In Wagner the Court of Appeals for the Third Circuit reviewed a National Highway Traffic Safety Administration order governing the performance of turn signal and hazard warning flashers. The agency had initially published a proposed order eliminating the permissible failure rates for flashers, but that order contained no reference to a change in the performance criteria of the flashers. ${ }^{132}$ The final order, however, substantially downgraded these performance criteria. ${ }^{133}$ The agency contended that this change was valid because notice of its intention to eliminate permissible failure rates gave interested parties a sufficient opportunity to comment on the entire subject inatter of the final standard. ${ }^{134}$ In addition, the agency noted that certam comments froin flasher manufacturers did discuss the desirability of down-

128. See, e.g., Taylor Diving \& Salvage Co. v. Department of Labor, 599 F.2d 622, 626 (5th Cir. 1979) (the contested provision in the standard finally promulgated was a logical outgrowth of provisions found in the standard originally proposed).

129. This factor follows from the dictum in International Harvester, which indicates that changes based in part on submitted comments are valid. See text accompanying note 115 supra.

The South Terminal court also placed some importance on the EPA's notice of rulemaking because it stated that the proposed plan umight be modified in light of submitted comments. See text accompanying note 120 supra. This statement alone, lowever, does not justify upholding substantially revised final rules in the absence of adequate notice. Because the notice requirement in 5 U.S.C. $\$ 553(b)(3)$ (1976) was designed to fairly apprise interested parties of significant issues involved in the rulemaking, see notes 26-27 supra and accompanying text, knowledge that the agency was considering alternatives or clianges in their proposed rule would not, in itself, give interested parties notice of final alternatives or clianges that were not indicated by the proposed rule.

130. See, e.g., American Standard, Inc. v. Umited States, 602 F.2d 256, 268 (Ct. Cl. 1979) (treasury regulations were invalidated because the mitial proposal did not give the public fair notice of the agency's intent with respect to the regulations' final form).

131. 466 F.2d 1013 (3d Cir. 1972).

132. 49 C.F.R. $\$ 571.108$ (1980). This proposed order was actually the agency's second published notice of rulemaking. The order promulgated pursuant to the first notice liad been withdrawn on Wagner's request because it mcluded a provision for omitting sampling procedures that the first notice did not mention or indicate. 466 F.2d at 1016. The notice in question was then issued to include a proposal to omit the sampling procedures. Id. at 1017.

133. 466 F.2d at 1018 .

134. Id. at 1019. 
grading flasher performance criteria. ${ }^{135}$ The court, without specifically discussing the factors later identified in South Terminal, rejected this contention, concluding that the agency's proposed standard provided inadequate notice of its final standard because it failed to apprise all interested parties of the issue of performance criteria. ${ }^{136}$

The inost significant aspect of Wagner is that the court remanded the substantially revised final standard for additional notice and comment, expressly refusing to sustain it even though the revisions related in part to comments received froin interested parties on the desirability of downgrading the flasher performance criteria. ${ }^{137}$ Under this approach, an agency cannot remedy a defective notice simply by poimting to some comments im the record that relate to the changes incorporated in the final rule. ${ }^{138}$ Together, Wagner and South Terminal ${ }^{139}$ suggest that for the courts to uphold a substantially changed final rule, they must be satisfied that the changes are sufficiently related to both the proposed rule and the submitted comments.

A strict application of the two factors recognized in South Terminal can provide affected parties with adequate protection when a final rule is changed substantially from its proposed form. By requiring that

135. Id.

136. Id. at 1020-21. The court also drew support for this conclusion from the failure of certain state agencies and consumer groups, which were vitally affected by the final standard, to offer any comments relating to performance criteria. The court viewed this absence of comment as evidence that the notice did not apprise imterested parties of the subject and issue imvolved. Id. at 1019-20.

137. When refusing to sustain the final standard the court stated: "The fact that some knowledgeable manufacturers appreciated the intimate relationship between the permissible failure ratc provisions and the performance criteria, and so responded, is not relevant. Others possibly not so knowledgeable also were mterested persons within the meaning of 5 U.S.C. $\$ 553$." 466 F.2d at 1019.

The court also placed hittle importance on the warning, included in the notice of proposed rulemaking, that "[t]he agency does not . . . accept the proposition that every change in detail made from a notice of proposed rule making inust be resubmitted as a proposal before a final rule may be issued." Id. at 1017. Like the warning in South Terminal, see text accompanying note 120 supra, this statement could not, in itself, remedy a defective notice.

138. See text accompanying note 116 supra. Conversely, some courts have held that interested parties cannot complain of the lack of opportunity to offer meaningful comment if the agency's preliminary rules gave sufficient notice of the substance and scope of the final rule. See Association of Am. R.Rs. v. Adams, 485 F. Supp. 1077, 1084-85 (D.D.C. 1978). In Adams the court rejected the petitioner's claim that a party who agreed with the agency's initial proposal has a right to refraim from commenting thereon and then to insist that the proposed rule not be changed to his detriment. See also American Frozen Food Inst. v. Train, 539 F.2d 107, 134 (D.C. Cir. 1976) (final EPA regulations were procedurally valid because the proposed regulation fully informed petitioners of the terms that might be miposed); National Indus. Traffic League v. United States, 396 F. Supp. 456, 460 (D.D.C. 1975) (final agency requirements were held to be well withim the agency's notice of proposed action).

139. See text accoinpanying notes $128-38$ supra. 
substantial changes be sufficiently related to both the proposed rule and the submitted comments, a reviewing court ensures that the agency's procedures satisfy the two purposes of notice and comment rulemaking. ${ }^{140}$ First, the court's determination that the proposed rule suffciently apprises interested parties of the subject inatter and scope of the final rules ensures that those parties had adequate prior notice of the nature and effect of the pertinent rules. ${ }^{141}$ Second, the court's finding that the substantial changes incorporated in the final rule relate to the comments received from interested parties ensures that the agency has responded to those parties' views and therefore has afforded them a meaningful opportunity to participate in the rulemaking process. ${ }^{142}$

The First Circuit's decision in Wyandotte illustrates the probleins that can result when a court fails to apply these factors strictly. The Wyandotte court concluded that the EPA's substantial rule changes were sufficiently related to the interim regulations and the submitted comments even though the petitioners were not aware of the changes until publication of the final regulations. ${ }^{143}$ Further, the court found the changes were precisely the opposite of those the petitioners advocated im their comments. ${ }^{144}$ This broad application of South Terminal subjected affected manufacturers to substantially revised standards that were not foreshadowed by either the interim regulations or the comments advanced during the rulemaking process. Interested parties did not receive effective notice of the final rules and had no real opportunity to comment on the rules finally adopted. The court could have remedied these probleins by ordering the EPA to impose an additional period of notice and comment.

\section{Substantial Change Between Interim and Final Rules: The NeEd for an AdDitional Notice AND COMMENT PERIOD}

The Wyandotte decision is troublesome for another reason: the court's holding had an even more adverse impact on the parties be-

140. See notes 26-32 supra and accompanying text.

141. See text accompanying note 31 supra. When determining whether the proposed rule has provided adequate notice of the final rule's scope and substance, the lack of public comments will often be an important factor. See Wagner Elec. Corp. v. Volpe, 466 F.2d 1013, 1019-20 (3d Cir. 1972) (failure of certain vitally affected groups to offer comments relating to a significant change incorporated in the final rule indicated that the proposed rule did not afford them adequate notice); National Resources Defense Council v. SEC, 389 F. Supp. 689, 700 n.9 (D.D.C. 1974) (small response to proposed rules indicated inadequate notice of their importance).

142. See text accompanying note 32 supra.

143. See text accoinpanying note 82 supra.

144. See text accoinpanying note 83 supra. 
cause the agency initially published interim, rather than proposed, regulations. ${ }^{145}$ Interim rules, unlike proposed rules, take effect immediately upon publication and carry the force of law. ${ }^{146}$ The impact of an interim rule is, therefore, much greater than that of a proposed rule; affected parties are required to comply with the interim rule's provisions even though they have had little or no opportunity to comment on the interim provisions. ${ }^{147}$

This greater impact is exacerbated by the usually long delay between the time the agency publishes an interim rule and the time it adopts a final rule. ${ }^{148}$ Because of this delay, an interim rule remains in effect for a substantial period of time, forcing affected parties to develop ineans to comply witl the interim rule's provisions. When an agency thereafter promulgates a final rule that differs substantially from its interim rule, it frustrates affected parties' reliance on the interim rule and forces them to readjust to vastly different standards and provisions. In Wyandotte the interim regulations had been in effect for over seventeen inonths before the agency promulgated its substantially revised final regulations. ${ }^{149}$ Affected parties were therefore subjected to completely different effluent limitations after liaving been required to comply with the interim regulations for almost one and a half years; further, they were without effective notice of the changes until publication of the final regulations. ${ }^{150}$

145. $598 \mathrm{~F} .2 \mathrm{~d}$ at 640 .

146. The interim rule is put into effect immediately, usually because of unavoidable limitations of time or the urgency of the conditions the rule is designed to correct. HouSE REPORT, supra note 11, at 25-26, reprinted in APA LeGisLATIVE HiSTORY, supra note 2, at 259-60; see United States Steel Corp. v. EPA, 605 F.2d 283, 285 (7th Cir. 1979) (promulgation of interim air quality standards within a short period after the passage of the Clean Air Act Amendments of 1977 was necessitated by Congress's tight statutory deadline), cert. denied, 444 U.S. 1035 (1980); Nader v. Sawhill, 514 F.2d 1064 (Tenip. Enier. Ct. App. 1975) (the Cost of Living Council proinulgated an immediate one dollar per barrel increase in the inaximuin ceiling price of "old" oil because of the urgent need to reduce the large discrepancy between domestic crude and world crude prices); Reeves v. Simow, 507 F.2d 455 (Temp. Enier. Ct. App. 1974) (gasoline regulations were made immediately effective because the long lines and violence resulting from a gas sliortage required prompt action).

147. See text acconipanying notes 18-25 supra.

148. See Consolidated Coal Co. v. Costle, 604 F.2d 239, 246 (4th Cir. 1979) (18-month and 11inonth delays between promulgation of EPA interim and final regulations); National Crusled Stone Ass'n v. EPA, 601 F.2d 111, 112 (4th Cir. 1979) (13-inonth delay between promulgation of interim and final rules); BASF Wyandotte v. Costle, 598 F.2d 637 (1st Cir. 1979) (17 1/2-1nonth delay), cert. denied, 444 U.S. 1096 (1980). Congress has considered sevcral bills that would have alleviated this problein by replacing the APA's good-cause exceptions with a provision allowing interim or einergency rules to remain in effect for no more than six or seven months. See Hearings on 1976 Amendments, supra note 95, at 487; S. 1070, 86th Cong., 1st Sess. \$ 1003(d) (1959), reprinted in 24 AD. L. REv. 412, 420-21 (1972).

149. 598 F.2d at $640-41$.

150. Id. at 642 . 
Imposition of an additional period of notice and comment in $W y$ andotte would have significantly benefitted those subject to the final regulations. By deferring the effective date of the final rule, an additional comment period would have given affected parties an opportunity to point out flaws or problems in the substantial revisions before those revisions became effective. An additional period also would have given affected parties time to prepare for the impact of the final regulations and to take any action that the issuance of the final regulations 1might have prompted. ${ }^{151}$ Most important, the comments received during this period would have given the Wyandotte court a more complete record on which to review the substantive validity of the revisions. ${ }^{152}$

In upholding the agency's procedures, the Wyandotte court based its conclusion partly on a determination that the comments received would not have differed fundamentally even if the commentators had known what changes the agency would ultimately incorporate in the final regulations. ${ }^{153}$ If the court had imposed an additional notice and comment period, however, it would not have had to make this determination; instead, comments on the substantial changes would have been in the record and available for the court to review. The court could have actually determined whether these comments differed fundamentally from the comments on the interim regulations and whether there was any merit to the comments.

Imposing an additional notice and comment period in cases in which interim rules are substantially revised would have no appreciable effect on the efficiency of the administrative rulemaking process. An additional notice and comment period would not delay the promulgation of effective rules because interim rules would already be in force. Imposing the additional notice and comment period on substan-

151. See Senate Report, supra note 2, at 15, reprinted in APA Legislative History, supra note 2 , at 201 . The purpose of the requirement that agencies publish substantive rules at least thirty days before the rule's effective date is to provide an opportunity for parties to prepare for the impact of the rule. 5 U.S.C. \& 553(d) (1976). In the case of interim rules, however, affected parties are deprived of this preparatory period because the rules are effective immediately upon publication. It is appropriate, therefore, that affected parties should have an additional opportunity to prepare for the final rule's effect, especially because the final rule differs substantially from the imterim rule that the parties have had to follow.

152. Under 5 U.S.C. $\S 706$ (1976), a court is required to review the administrative record when determining the vahdity of agency action. Although there is some dispute about whether the rulemaking record is what was before the agency when it issued rules or what is assembled for review, see K. DAvis, supra note 29 , at $\$ \$ 6: 5,6: 10$, it is clear that the public comments received by an agency constitute an important part of that record and, thus, additional comments provide courts with a broader and more complete basis for review. See Rodway v. United States Dep't of Agriculture, 514 F.2d 809, 817 (D.C. Cir. 1975) (the absence of comments makes the appellate function impossible).

153. 598 F.2d at 643. 
tially revised interim rules would not leave unregulated the parties or subjects covered by the rules. Rather, the interim rules would remain in effect during this additional period until the final rules became effective. ${ }^{154}$

More important, the agencies' arguinent that requiring an additional notice and comment period for substantially revised rules would urmecessarily delay the rulemaking process ${ }^{155}$ is unpersuasive with respect to interim rules. An agency that publishes interim rules has already avoided delay in the proinulgation of effective rules. The agency, by demonstrating good cause, avoids both extensive notice and comment before promulgation of the interim rule and the usually required thirty-day deferral period between publication of a rule and its effective date. ${ }^{156}$ An agency that is afforded these procedural advantages ${ }^{157}$ has no reason to complain about giving affected parties an additional opportunity to respond to substantial changes in the final rule. After all, the affected parties have little or no opportumity to comment on the interim rules before their promulgation, the substantial changes have a significant impact on affected parties, and the interim rule remains in effect during the additional notice and comment period.

\section{CONCLUSION}

Substantial change in an administrative rule between its proposed and final stages raises serious questions about the adequacy of an agency's notice and comment rulemaking procedures. An agency's proposed rule, along with the submitted comments, may not give interested parties sufficient notice of the scope and substance of a substantially revised final rule. Consistent with the recent developments of more stringent rulemaking notice requirements, courts should strictly review proposed rules that undergo substantial change to ensure that the revisions are sufficiently related to both the proposed rule and the comments. Strict review is particularly important in light of the notice and comment procedures' purpose of producing reasoned and informed administrative rulemaking.

154. Because an agency is required to demonstrate good cause before promulgating immediately effective interim rules, 5 U.S.C. \& 553(d)(3) (1976), this showing of good cause permits the interim rule to remaim in effect until a permanent rule is promulgated and inade effective. See notes 20-22 supra and accompanying text.

155. See text accompanying notes 101-03 supra.

156. This avoidance assumes that the interim rule was properly promulgated in accordance with the APA's good-cause exceptions. See notes 18-21 supra and accompanying text.

157. 5 U.S.C. § 553(d) (1976). A recent case reinforced the original intention of this section: that the deferral period was meant to start upon publication of the rule as ultimately adopted and not with publication of the proposed rule. Rowell v. Andrus, 631 F.2d 699 (10th Cir. 1980). 
Moreover, although courts have been reluctant to impose additional rulemaking procedures on agencies, ${ }^{158}$ the significant consequences that result from substantial changes in a long-standing interim rule justify a more frequent imposition of an additional notice and comment period when an agency publishes a final rule that differs substantially froin its preceding interim rule. This additional period would give parties affected by the agency's rule an opportunity to address the rationality and desirability of the changes while providing courts with a more complete record on which to review the substantive validity of the changes. The end result would be greater public participation and better informed agency rulemaking without a sacrifice of administrative rulemaking efficiency.

Mark D. Shepard

158. Imposing an additional notice and comment period would not run afoul of the Supreme Court's holding in Vermont Yankee because this additional court-imposed procedure is warranted by a finding that the agency's notice of rulenaking fails to satisfy the purposes underlying the APA's minimum notice provisions. See text accompanying notes 68-73 supra. 